\title{
UPAYA PENINGKATAN HASIL BELAJAR KELOMPOK SISWA DENGAN METODE CERAMAH MELALUI STRATEGI PEMBELAJARAN PENINGKATAN KETERAMPILAN BERPIKIR (SPPKB) PADA BIDANG STUDI IPS TERPADU DI SMPN 2 JEROWARU
}

\author{
Muhamad Zaril Gapari \\ STIT Palapa Nusantara \\ zagap205@yahoo.co.id
}

\begin{abstract}
Education is one that everyone should follow. With adequate education someone will be able to answer the global challenges in life. With this education also the dignity of a person will be lifted, the lower the level of education of a person, the dignity of the environment is also low. The dignity of the Indonesian nation in the eyes of the world is also influenced by the education of its population. One indication of the achievement of the education process is the realization of satisfactory learning outcomes. Education can be said to be successful if good learning outcomes are achieved or students get grades above average. The purpose that has been determined in this study, namely to improve student group learning outcomes with the lecture method through learning strategies to increase thinking skills (SPPKB) in the integrated IPS subject for class VII at SMP N 2 Jerowaru. Therefore, to achieve this goal, the researchers tested 28 students as samples with 11 male and 17 female samples taken from the total population. This type of research is classroom action research (PTK) which consists of two cycles and each cycle consists of two meetings. The research instrument used to determine the level of understanding of students was a descriptive test (subjective) which was then analyzed by learning completeness criteria, while to determine the activities of students and teachers using observation sheets. Based on the results of the research, after analyzing the data, it was obtained data on students' understanding of cycle I in student discussion group activities of $74.4 \%$ with an average of 2.6 and $50 \%$ completeness of student learning with an average of 59.3. while in cycle II the percentage of student discussion group activities was $87.2 \%$ with an average of 3.1 and the percentage of student learning completeness as much as $89.1 \%$ with an average value of 72.1 .
\end{abstract}

Keywords: Group Discussion, Learning Achievement

\begin{abstract}
Abstrak : Pendidikan merupakan salah satu yang harus diikuti oleh semua orang. Dengan pendidikan yang memadai seseorang akan mampu menjawab tantangan-tantangan global dalam kehidupan. Dengan pendidikan ini pula harkat dan martabat seseorang akan terangkat, semakin rendah tingkat pendidikan seseorang martabat dilingkungannya juga rendah. Harkat dan martabat bangsa Indonesia di mata dunia juga di pengaruhi pendidikan penduduknya. Salah satu indikasi pencapaian proses pendidikan tersebut adalah terwujudnya hasil belajar yang memuaskan. Pendidikan dapat dikatakan berhasil apabila tercapai hasil belajar yang baik atau siswa mendapatkan nilai diatas rata-rata. Tujuan yang telah ditentukan dalam penelitian
\end{abstract}


ini, yakni untuk meningkatkan hasil belajar kelompok siswa dengan metode ceramah melalui strategi pembelajaran peningkatan kemampuan berpikir (SPPKB) pada bidang studi ips terpadu untuk kelas VII di SMPN 2 Jerowaru. Oleh karena itu, untuk mencapai tujuan terebut peneliti menguji 28 siswa sebagai sampel dengan spesifikasi laki-laki 11 orang dan perempuan 17 orangyang diambil dari jumlah keseluruhan populasi. Jenis penelitian ini adalah penelitian tindakan kelas (PTK) yang terdiri dari dua siklus dan tiap-tiap siklus terdiri dari dua kali pertemuan. Instrumen penelitian yang digunakan untuk mengetahui tingkat pemahaman siswa adalah tes uraian ( subyektif) yang kemudian dianalisis dengan kriteria ketuntasan belajar, sedangkan untuk mengetahui aktifitas siswa dan guru yaitu dengan menggunakan lembar observasi. Berdasarakan hasil penelitian setelah dilakukan analisis terhadap data tersebut diperoleh data pemaahaman siswa siklus I pada aktifitas kelonpok diskusi siswa $74.4 \%$ dengan rata-rata 2.6 dan ketuntasan ketuntasan belajar siswa $50 \%$ dengan rata-rata 59.3. sedangkan pada siklus II persentase aktifitas kelompok diskusi siswa sebanyak $87.2 \%$ dengan rata-rata 3.1 dan persentase ketuntasan belajar siswa sebanyak $89.1 \%$ dengan nilai rata-rata 72.1 .

Kata Kunci: Diskusi Kelompok, Prestasi Belajar

\section{PENDAHULUAN}

Dewasa ini perkembangan ilmu pengetahuan dan teknologi semakin pesat. Bangsa-bangsa yang ingin maju berusaha meningkatkan mutu pendidikan, misalnya dengan menyusun kurikulum yang disesuaikan dengan perkembangan jaman, karena perkembangan ilmu pengetahuan dan teknologi sangat ditunjang oleh keberhasilan dalam dunia pendidikan. Dalam rangka meningkatkan mutu pendidikan, salah satu usaha yang dapat dilakukan ialah dengan memahami bagaimana informasi yang diperoleh dari lingkungan diproses dalam pikiran, sehingga mampu untuk dikembangkan. Dalam kaitannya dengan kemajuan ilmu pengetahuan dan teknologi, peranan ekonomi sangat membantu. Akan tetapi sampai saat ini pelajaran ips ekonomi masih merupakan mata pelajaran yang kurang disukai dan dianggap tidak menyenangkan dibandingkan dengan mata pelajaran yang lain. Upaya dalam memperbaiki mutu pendidikan ekonomi telah banyak dilakukan dengan mencoba menerapkan berbagai macam metode dan model pembelajaran.

Berdasarkan pengalaman empiris, kurang kreatifnya guru dalam melakukan inovasi pembelajaran memiliki pengaruh yang cukup signifikan terhadap kemampuan siswa dalam menguasai kompetensi yang seharusnya dicapai. Metode rill yang dilakukan menjelang pelaksanaan UN misalnya, dinilai terlalu banyak memberikan 
intervensi dan tekanan psikologis kepada siswa. Akibatnya, siswa cenderung hanya mampu menjadi penghafal kelas satu dari pada menjadi seorang pembelajar yang haus ilmu pengetahuan.

Mereka diperlakukan secara mekanis bagaikan robot sehingga tidak memiliki kesempatan untuk melakukan refleksi dan pendalaman materi ajar. Untuk menyampaikan pengalaman yang dimiliki kepada peserta didik, seorang guru harus mempunyai strategi pembelajaran. Di dalam strategi pembelajaran meliputi metode atau pun model pembelajaran yang sesuai dengan materi pelajaran, sehingga dapat meningkatkan motivasi dan hasil belajar siswa. Tetapi kebanyakan seorang guru masih mengidolakan model pembelajaran konvensional yang cenderung lebih mudah dan tidak membutuhkan keterampilan khusus bagi guru untuk menerapkannya. Padahal, model pembelajaran ini tidak memberikan stimulus kepada siswa untuk aktif dan kreatif.

Begitu juga dari peneliti memperhatikan pada proses belajar mengajar yang berlangsung di SMPN 2 Jerowaru masih menggunakan model pembelajaran konvensional yang cenderung membuat suasana kelas monoton dan hasil belajarnya rendah. Untuk itu perlu ditingkatkan hasil belajar siswa khususnya kemampuan kognitif dalam memecahkan masalah serta aktivitas siswa.

Dipandang dari subyek belajar yaitu siswa, maka segenap potensi yang dimiliki siswa menjadi sangat penting dalam menentukan arah dan tujuan pendidikan karena keberhasilan pendidikan akan dikembalikan kepada siswa itu sendiri, berdasarkan informasi yang diperoleh dari guru, bahwa hasil belajar siswa relatif rendah. Hal ini dapat dilihat dari hasil belajar siswa pada materi yang diajarkan belum mencapai Standar Ketuntasan Belajar Mengajar (SKBM) dengan nilai tes belajar 65. Sementara nilai ketuntasan belajar yang ditetapkan oleh sekolah minimal mendapat nilai 75 .

Adapun yang menjadi indikator untuk mengukur hasil belajar siswa adalah meningkatnya nilai ekonomi yang ditandai dengan tercapainya kreteria ketuntasan minimum $(\mathrm{KKM})$ yaitu tercapainya skor $\geq 75$ dan klasikal $85 \%$ berdasarkan KKM yang telah ditetapkan oleh pihak sekolah, guru serta komite sekolah. Jadi setiap siswa dalam proses belajar mengajar dikatakan tuntas terhadap mata pelajaran ekonomi apabila memperoleh $\geq 75$. 
Oleh karena itu pembelajaran ekonomi perlu mengembangkan berbagai metode keterampilan dan strategi dalam pembelajaran ekonomi. Tujuannya antara lain agar di dalam pembelajaran terdapat motivasi atau semangat dari siswa. Di samping menguasai metode pembelajaran, guru juga harus menguasai teknik menerangkan, mengajarkan konsep ekonomi, membangkitkan motivasi siswa, menggunakan alat bantu dan mengevaluasi sampai seberapa jauh proses belajar mengajar dalam kelas telah tercapai.

Salah satu model yang dapat dikembangkan dalam upaya memperbaiki mutu pembelajaran ekonomi adalah dengan memadukan model pembelajaran. Oleh karena itu untuk meningkatkan hasil belajar siswa peneliti mencoba untuk menerapkan metode penggunaan Presentasi (Advance Organizer) terhadap hasil belajar di SMPN 2 Jerowaru.

Manusia adalah mahluk ciptaan tuhan yang paling sempurna di muka bumi ini. Selain memiliki ciri-ciri fisik yang khas juga dilengkapi dengan kemampuan inteleginsia dengan daya nalar yang tinggi sehingga menjadi manusia yang mampu untuk berfikir, berbuat dan bertindak kearah berkembangnya sebagai manusia yang utuh. Kemampuan itulah yang tidak di miliki oleh mahluk tuhan yang lainnya seperti binatang, tumbuhan dan yang lainnya dalam kaitannya dengan perkembangan individu, manusia dapat tumbuh dan berkembang melalui suatu proses yaitu proses alami menuju kedewasaan fisik jasmani maupun rohani. Oleh sebab itu untuk menuju kearah perkembangannya manusia yang optimal sesuai dengan potensi kemampuan yang di milikinya. Manusia memerlukan pendidikan sebagai proses dan usaha sadar untuk lebih memanusiakan manusia.

Pendidikan merupakan salah satu yang harus diikuti oleh semua orang. Dengan pendidikan yang memadai seseorang akan mampu menjawab tantangantantangan global dalam kehidupan. Dengan pendidikan ini pula harkat dan martabat seseorang akan terangkat, semakin rendah tingkat pendidikan seseorang martabat dilingkungannya juga rendah. Harkat dan martabat bangsa Indonesia di mata dunia juga di pengaruhi pendidikan penduduknya.

Salah satu indikasi pencapaian proses pendidikan tersebut adalah terwujudnya hasil belajar yang memuaskan. Pendidikan dapat dikatakan berhasil apabila tercapai hasil belajar yang baik atau siswa mendapatkan nilai diatas rata-rata. 
Hasil beajar adalah hasil yang diperoleh berupa kesan-kesan yang mengakibatkan perubahan dalam diri individu sebagai hasil aktivitas dalm belajar. ${ }^{1}$ Sedangkan pendapat lain mengungkapkan bahwa hasil belajar adalah hasil yang dicapai individu setelah yang bersangkutan mengalami proses atau diajarkan suatu pengetahuan. Tentang hasil belajar ini bisa disebut kecakapan nyata, kecakapan aktual yang diperoleh seseorang setelah belajar suatu kecakapan atau pengetahuan tertentu. ${ }^{2}$

Perbedaan hasil belajar bagi siswa kelas VII di SMPN 2 Jerowaru disebabkan oleh faktor-faktor, antara lain kematangan akibat kemajuan, umur kronologis, latar belakang pribadi, sikap dan bakat terhadap suatu bidang pelajaran atau jenis mata pelajaran yang diberikan. Pada proses pencapaian hasil belajar yang baik, diperlukan juga suatu latihan dan ulangan terhadap suatu pelajaran. Dari analisis pembuatan soal yang dibuat oleh guru ditemukan kurang adanya penekanan upaya mengukur keterampilan berpikir rasional siswa. Melihat dari hasil ulangan harian siswa yang masih dibawah KKM yaitu nilai rata-rata kelasnya 55 sedangkan KKM yang ditentukan oleh guru adalah 60 .

Untuk mengatasi hal tersebut diatas strategi-strategi pembelajaran banyak diterapkan oleh para ahli pendidikan dalam pencapian tujuan. Misalnya model pembelajaran dengan menggunakan strategi pembelajaran kemampuan berpikir (SPPKB). Strategi yang ditawarkan ini merupakan strategi pembelajaran yang menempatkan pada kemampuan berpikir siswa.

Strategi ini pada awalnya dirancang untuk pembelajaran ilmu pengetahuan sosial ( IPS ), sebab banyak orang yang berasumsi bahwa IPS merupakan pelajaran hapalan untuk itu strategi pembelajaran ini mencoba menghapus asumsi-asumsi orang terhadap mata pelajaran IPS dengan menawarkan SPPKB pada peserta didik yang tentunya bisa dihubungkan dengan kehidupan sehari-hari. ${ }^{3}$

Metode ceramah adala sebuah metode mengajar dengan menyampaikan imformasi kepada sejumlah siswa. Cara mengajar dengan ceramah dapat pula

\footnotetext{
${ }^{1}$ Syaiful Bahri. Prestasi dan Konpentensi Guru. (Surabaya: Usaha Nasional 1994), 23.

2 Wayan Nurkancanta. Evaluasi pendidikan. (Surabaya : Karya Usaha 1986), 2.

${ }^{3}$ Wina Sanjaya. Strategi Pembelajaran. (Bandung : Kencana 2006), 224.
} 
dikatakan sebagai suatu cara mengajar dengan menyampaikan keterangan atau informasi atau uraian tentang suatu pokok persoalan serta masalah secara lisan. ${ }^{4}$

Metode ceramah adalah metode mengajar tertua dan tidak perlu banyak persiapan untuk menjelaskannya. Dan dengan alasan ini pulalah banyak guru memilih metode ini. Tetapi berdasarkan penelitian sangat sedikit materi yang dapat diserap oleh siswa karna siswa hanya mendengarkan. Sehubungan dengan itu maka penulis akan melakukan penelitian tentang " Upaya Peningkatan Hasil Belajar Kelompok Siswa Dengan Metode Ceramah Melalui Strategi Penbelajaran Peningkatan Kemampuan Berpikir (SPPKB) Pada Bidang Studi IPS Terpadu Untuk Kelas VII di SMPN 2 Jerowaru."

\section{METODE PENELITIAN}

Jenis penelitian yang digunakan dalam penelitian ini adalah penelitian tindakan kelas. Penelitian Tindakan kelas ini merupakan suatu pencermatan terhadap kegiatan belajar berupa sebuah tindakan yang sengaja dimunculkan dan terjadi dalam sebuah kelas secara bersama. ${ }^{5}$ Penelitian Tindakan Kelas (PTK) merupakan penelitian yang dilakukan oleh guru di kelasnya sendiri melalui refleksi diri dengan tujuan untuk memperbaiki kinerja hasil belajar siswa meningkat. ${ }^{6}$

Penelitian Tindakan Kelas ini juga menekankan pada kegiatan yang menguji cobaan suatu ide dalam praktik atau situasi nyata dalam skala mikro yang di harapkan kegiatan tersebut mampu memperbaiki dan meningkatkan kualitas proses belajar mengajar. Penelitian tindakan kelas ini dilakukan untuk meningkatkan hasil belajar kelompok siswa dengan metode ceramah melalui Strategi Pembelajaran Peningkatan Keterampilan Berpikir (SPPKB) Di Kelas VII SMPN 2 Jerowaru .

Penelitian Tindakan Kelas ini dilaksanakan di SMPN 2 Jerowaru, dengan tujuan untuk mengetahui bagaimana kemampuan siswa di dalam menelaah faktafakta yang ada melalui kemampuan berpikirnya. Subyek penelitian ini adalah siswa kelas VII di SMPN 2 Jerowaru dengan jumlah siswa 28 orang yang terdiri dari 11 siswa laki- laki dan 17 siswa perempuan. Metode pengumpulan data penelitian ini

\footnotetext{
${ }^{4}$ Syaiful Sagala. Kemampuan Propesi Guru. (Jakarta: Rineka cipta 2002), 202.

${ }^{5}$ Arikunto. Prosedur Penelitian Suatu Pendekatan Praktek. (Jakarta: Rineka Cipta 2002), 3.

${ }^{6}$ Aqib, dkk. Penelitian Tindakan Kelas, Untuk Guru SMP, SMA, SMK. (Bandung: Yrama Widya 2008), 2.
} 
dengan observasi dan tes. Sedangkan teknik analisis data penelitian ini adalah data aktivitas siswa dan data hasil belajar siswa.

\section{HASIL PENELITIAN}

Adapun hasil dari penelitian ini dalam Upaya Peningkatan Hasil Belajar Kelompok Siswa Dengan Metode Ceramah Melalui Strategi Penbelajaran Peningkatan Kemampuan Berpikir (SPPKB) Pada Bidang Studi IPS Terpadu Untuk Kelas VII di SMPN 2 Jerowaru melalui data aktivitas siswa, data aktivitas guru.

\section{A. Data Aktivitas Siswa}

Berdasarkan hasil evaluasi setelah pelaksanaan tindakan dengan menerapkan strategi pembelajaran peningkatan kemampuan berpikir (SPPKB) menunjukkan hasil yang baik, walaupun pada siklus I belum mencapai taraf ketuntasan klasikal tetapi pada siklus II terjadi peningkatan yakni Rata-rata pada aktivitas diskusi siklus I sebesar 2,6 dan siklus II sebesar 3,1, sedangkan rata- rata pada aktivitas siswa pada siklus I sebesar 59,3 dan pada siklus II sebesar 72,1.

Berdasarkan data tersebut dicari mean ideal dan standar deviasi ideal guna memperoleh pengkategoriannya. Rata-rata mean ideal (Mi) dan standar deviasi ideal (SDi) untuk aktivitas diskusi dan aktivitas siswa dapat dicari dengan rumus yakni Untuk aktivitas diskusi :

$$
\begin{aligned}
\text { Rata- rata ideal }(\mathrm{Mi}) & =1(3,1+2,6) \\
& =2,7 \\
\mathrm{SDi} & =1(3,1-2,6) \\
& =0,3
\end{aligned}
$$

Untuk aktivitas siswa :

$$
\begin{array}{ll}
\text { Rata- rata mean ideal }(\mathrm{Mi}) & =1(72,1+59,3) \\
& =65,7 \\
\text { SDi } & =1(72,1-59,3) \\
& =2,2
\end{array}
$$

Jadi dengan demikian dapat kategorikan dalam table berikut ini:

1. Aktivitas diskusi

Table 01. Kriteria Mean Ideal dan Standar Deviasi Aktivitas Kelompok 
2. Aktivitas siswa

\begin{tabular}{|c|c|c|}
\hline No & Interval & Kategori \\
\hline 1 & $\begin{array}{l}\mathrm{Mi}+1 \text { SDi s/d Mi }+3 \text { SDi } \\
2,7+10,3 \text { s/d 2,7 + 30,3 } \\
3 \text { s/d } 3,6\end{array}$ & Tinggi \\
\hline 2 & $\begin{array}{l}\mathrm{Mi}-1 \mathrm{SDi} \text { s/d Mi }+1 \mathrm{SDi} \\
2,7-10,3 \mathrm{~s} / \mathrm{d} 2,7+10,3 \\
2,4 \text { s/d } 3\end{array}$ & Sedang \\
\hline 3 & $\begin{array}{c}\text { Mi - } 3 \text { SDi s/d Mi - } 1 \text { SDi } \\
2,7-30,3 \text { s/d 2,7 - 10,3 } \\
-1,8 \text { s/d } \quad 2,4\end{array}$ & Kurang \\
\hline
\end{tabular}

Tabel 02. Kriteria Mi dan SDi Aktivitas Siswa

\begin{tabular}{|c|c|c|}
\hline No & Interval & Kategori \\
\hline 1 & $\begin{array}{l}\mathrm{Mi}+1 \text { SDi s/d Mi }+3 \text { SDi } \\
65,7+12,2 \text { s/d } 65,7+32, \\
67,9 \quad \text { s/d } 72,3\end{array}$ & Tinggi \\
\hline 2 & $\begin{array}{l}\text { Mi - } 1 \text { SDi s/d Mi + } 1 \text { SDi } \\
65,7-12,2 \text { s/d } 65,7+10,3 \\
63,5 \text { s/d } \quad 67,9\end{array}$ & Sedang \\
\hline 3 & $\begin{array}{c}\text { Mi - } 3 \text { SDi s/d Mi - } 1 \text { SDi } \\
65,7-32,2 \text { s/d } 65,7-12,2 \\
59,1 \quad \text { s/d } \quad 63,5\end{array}$ & Kurang \\
\hline
\end{tabular}

Adapun jumlah siswa 28 orang, dimana 28 orang dibagi menjadi 7 kelompok, masing masing kelompok terdiri dari 4 orang anak, pengelompokan ini digunakan sebagai model pembelajaran, dimana siswa melakukan diskusi dimasing-masing kelompok mereka dan untuk mengetahui tingkat pemahaman setiap kelompok diberikan LKS, masing-masing kelompok yang belum menyelesaikan soal-soal di LKS, kelompok tersebut diberikan kesempatan tanya jawab dengan kelompok lain. Sedangkan untuk mengetahui tingkat ketuntasan siswa diberikan soal individu yang terdiri dari 10 soal, seorang siswa dikatakan tuntas apabila telah memenuhi KKM 
yaitu dengan nilai 70, sedangkan untuk ketuntasan klasikalnya apabila $80 \%$ dari jumlah siswa sudah memenuhi KKM.

Adapun Hasil pelaksanaan tindakan dari penelitian tersebut adalah sebagai berikut :

1. Siklus I

a. Perencanaan

Adapun hal-hal pokok yang perlu dipersiapkan peneliti dalam melakukan tindakan untuk siklus I, yaitu:

1). Membuat Skenario Pembelajaran

2). Membuat kelompok yang memiliki kemampuan Akademik bersifat heterogen dengan anggota 4 orang.

3). Membuat kisi-kisi soal evaluasi.

4). Menyiapkan lembar kerja siswa (LKS) Kelompok dan individu.

5). Menyiapkan lembar observasi guru

6). Menyiapkan lembar observasi siswa

7). Menyiapkan Analisis hasil evaluasi aktifitas kelompok diskusi siklus I, II

8). Menyiapkan lembar analisis hasil evaluasi siklus I, II

\section{b. Pelaksanaan Tindakan}

Proses belajar mengajar dilaksanakan 2 kali pertemuan, tiap kali pertemuan terdiri dari 2 jam pelajaran atau 2 x 40 menit, adapun materi yang dibahas dalam siklus I adalah :

1). Pertemuan Pertama

Dalam pertemuan pertama peneliti membahas masalah hakekat manusia sebagai mahluk social dan ekonomi yang bermoral, disini guru menyampaikan materi berdasarkan skenario pembelajaran yang telah disusun sebelumnya dalam tahap perencanaan.

2). Pertemuan Kedua

Pada pertemuan kedua, peneliti memberikan tugas berupa latihan-latihan soal yang masih berkisar pada ipertemuan sebelumnya, yaitu masalah pembagian tindakan ekonomi dalan berbagai kegatan sehari-hari, dimana guru memberikan soal-soal dan siswa mengerjakan soal tersebut dengan tujuan memantapkan pemahaman siswa dalam materi tersebut, disini 
guru memberikan kebebasan kepada siswa untuk bertanya baik kepada teman sebangku maupun kepada peneliti sendiri dengan tujuan agar siswa berani mengungkapkan permasalahan yang mereka hadapi, karena pengakuan dari siswa sendiri bahwa sebelumnya mereka tidak diberi kesempatan untuk bertanya selama proses belajar berlangsung, dan setelah itu guru memberikan kesempatan kepada siswa untuk mengerjakan hasil dari latihan yang mereka kerjakan untuk dikerjakan ke papan tulis dan sementara teman yang lain menanggapi hasil dari temannya. Pada tahap akhir guru tidak lupa mengingatkan kepada siswa untuk mengulang kembali dirumah tentang materi yang mereka peroleh hari ini karena pertemuan berikutnya peneliti akan mengadakan evaluasi tentang materi tersebut dengan tujuan peneliti ingin mengetahui sejauh mana pemahaman siswa terhadap materi yang diajarkan oleh peneliti.

c. Hasil Pengamatan (observasi)

Hasil pengamatan observasi di sajikan dalam tabel di bawah ini:

Tabel 03. Rekapitulasi Hasil Observasi Aktifitas Kelompok Diskusi Siklus I

\begin{tabular}{|c|c|c|c|c|}
\hline Keterangan & Skor & $\begin{array}{c}\text { Jumlah } \\
\text { Nilai }\end{array}$ & $\begin{array}{c}\text { Nilai Rata - } \\
\text { Rata }\end{array}$ & Kriteria \\
\hline $\begin{array}{c}\text { Aktifitas Kelompok Siklus } \\
\text { I }\end{array}$ & 453 & 74,4 & 2,0 & $\begin{array}{c}\text { Kurang } \\
\text { Aktif }\end{array}$ \\
\hline
\end{tabular}

Dari tabel di atas menunjukkan bahwa rata-rata aktifitas kelompok diskusi siswa adalah 2,6. berdasarkan kriteria data aktifitas data yang telah ditetapkan diperoleh data rata-rata skor siswa untuk setiap aktifitas pada siklus I tergolong kurang aktif.

Tabel 03. Rekafitulasi Hasil evaluasi belajar siswa pada siklus I

\begin{tabular}{|c|c|c|}
\hline No & Jenis Penilaian & Hasil \\
\hline 1 & Skor terendah & 30 \\
\hline 2 & Skor tertinggi & 80 \\
\hline
\end{tabular}




\begin{tabular}{|c|c|c|}
\hline 3 & Rata - rata & 59,3 \\
\hline 4 & Jumlah siswa yang tuntas & 14 \\
\hline 5 & Jumlah siswa yang ikut tes & 28 \\
\hline 6 & Persentase yang tuntas & $50 \%$ \\
\hline
\end{tabular}

Dari tabel diatas dapat dilihat bahwa nilai rata - rata yang diperoleh pada siklus I adalah 59,3 masih belum memenuhi target kriteria ketuntasan minimal (KKM) yang telah ditentukan adalah 70. dan bila dilihat dari ketuntasan klasikalnya yang telah ditetapkan adalah $80 \%$ dari jumlah siswa yang mendapatkan nilai 70 hanya $50 \%$, sehingga dapat disimpulkan bahwa ketuntasan belajar secara klasikal belum tercapai.

Berdasarkan hasil pengamatan (bservasi), kemungkinan penyebab belum terciptanya suasana yang diharapkan dalam kegiatan pembelajaran adalah

1) Guru kurang mampu mengaitkan materi pelajaran dengan dunia Berdasarkan hasil pengamatan (observasi), kemungkinan penyebab belum terciptanya suasana yang diharapakan dalam kegiatan nyata.

2) Banyak diantara siswa yang kurang antusias dalam mengikuti kegiatan pembelajaran.

3) Masih kurangnya keberanian siswa dalam bertanya.

4) Kurangnya partisipasi siswa dalam menyimpulkan hasil belajar.

5) Kurangnya alokasi waktu yang disediakan untuk pelaksanaan kegiatan pembelajaran pada siklus pertama, khususnya pada saat pengembangan.

2. Siklus II

a. Hasil observasi

Dari hasil kegiatan pembelajaran pada siklus II diperoleh data kuantitatif sebagai berikut:

1) Keaktifan siswa dalam pelaksanaan pembelajaran relatif lebih baik dan hanya beberapa orang saja yang masih pasif.

2) Waktu pembelajaran yang dialokasikan (direncanakan) mencukupi untuk menyelesaikan materi yang direncanakan. 
3) Secara umum kegitan pembelajaran sudah berjalan dengan baik walaupun pada saat mengerjakan latihan ada siswa yang masih melihat jawaban temannya.

Tabel 04. Rekfitulasi hasil observasi aktifitas diskusi kelompok Siklus II

\begin{tabular}{|c|c|c|c|c|}
\hline Keterangan & Skor & $\begin{array}{c}\text { Jumlah } \\
\text { Nilai }\end{array}$ & $\begin{array}{c}\text { Nilai Rata - } \\
\text { Rata }\end{array}$ & Kriteria \\
\hline $\begin{array}{c}\text { Aktifitas Kelompok Siklus } \\
\text { II }\end{array}$ & 512 & 87,2 & 3,1 & Aktif \\
\hline
\end{tabular}

Dari tabel 05 menunjukkan bahwa nilai rata-rata aktifitas kelompok diskusi siswa mengalami peningkatan dimana pada siklus I nilai rata-rata 2,6 pada siklus II nilai rata-rata menjadi 3,1. Berdasarkan kriteria data diatas aktifitas yang telah ditetapkan diperoleh data rata - rata skor siswa disetiap aktifitas pada siklus II ini menjadi Aktif.

b. Evaluasi Hasil Belajar

Berdasarkan hasil evaluasi (penilaian) secara kuantitatif setelah pelaksanaan tindakan (kegiatan pembelajaran) menunjukkan hasil yang sesuai harapan yaitu berdasarkan analisis hasil ulangan harian mencapai taraf ketuntasan belajar secara klasikal (ketuntasan secara klasikal yang diperoleh 80\% dari 28 siswa )

Untuk lebih jelasnya hasil evaluasi pembelajaran di sajikan dalam tabel di bawah ini:

Tabel 05. Rekafitulasi Hasil Evaluasi belajar siswa pada siklus II

\begin{tabular}{|c|c|c|}
\hline No & Jenis Penilaian & Hasil \\
\hline 1 & Skor terendah & 50 \\
\hline 2 & Skor tertinggi & 90 \\
\hline 3 & Rata - rata & 72,1 \\
\hline 4 & Jumlah siswa yang tuntas & 25 \\
\hline 5 & Jumlah siswa yang ikut tes & 28 \\
\hline
\end{tabular}




\begin{tabular}{|c|c|c|}
\hline 6 & Persentase yang tuntas & $89,1 \%$ \\
\hline
\end{tabular}

Berdasarkan tabel 05 dapat dilihat bahwa nilai rata-rata yang diperoleh pada siklus II ini adalah 72,1 bila dibandingkan dengan persentase ketuntasan yang tercantum dalam kriteria ketuntasan minimal (KKM) 70 sudah memenuhi target didalam KKM nya. Dan apabila dilihat dari ketuntasan klasikal yang diperoleh mencapai 89,1\% dan sudah melebihi persentase ketuntasan klasikal yang telah ditentukan sebesar 80\%. Sehingga dapat ditarik kesimpulan bahwa pada siklus II ini ketuntasan belajar siswa secara klasikal sudah tercapai atau tuntas dan dapat dilihat dalam lampiran 10.

\section{B. Data Aktivitas Guru}

Adapun data ringkasan tentang kegiatan guru siklus I dan II dapat dilihat pada tabel berikut ini:

Tabel 06. Kategori kegiatan guru dalam proses pembelajaran siklus I dan siklus II

\begin{tabular}{|l|l|}
\hline \multicolumn{1}{|c|}{ Nilai Interval } & \multicolumn{1}{|c|}{ Kategori } \\
\hline 64,01 $<\mathrm{M} \leq \mathrm{M}$ 80.01 & Sangat aktif \\
$53,33<\mathrm{M} \leq \mathrm{M}$ 64,01 & Aktif \\
42,67 $<\mathrm{M} \leq \mathrm{M} \mathrm{53,33}$ & Cukup aktif \\
$15,99<\mathrm{M} \leq \mathrm{M} \mathrm{31,99}$ & Kurang aktif \\
$31,99 \leq \mathrm{M} \leq 42,67$ & Sangat kurang aktif \\
\hline
\end{tabular}

Berdasarkan hasil observasi pada siklus I dan siklus II skor yang diperoleh pada proses observasi kinerja guru untuk meningkatkan hasil belajar siswa dengan menggunakan strategi pembelajaran peningkatan kemampuan berpikir. Tergolong dalan kategori sangat aktif karena nilai rat-rata kedua siklus sama-sama berada pada interval $64,10<\mathrm{M} \leq \mathrm{M}$ 80,01 yaitu dengan rincian nilai rata-rata siklus I 66,5 dan siklus II 77,72.

\section{PEMBAHASAN}

Pendidkan merupakan salah-satu yang harus diikuti oleh semua orang, pendidikan ditujukan untuk mencerdaskan kehidupan bangsa dan meningkatkan kualitan sumberdaya manusia melalui upaya peningkatan kualitas pendidikan. Melalui pendidikan bangsa indonesia mampu membebaskan diri dari keterbelakangan. 
Salah satu indikasi pencapaian proses pendidikan tersebut adalah terwujudnya hasil belajar yang memuaskan .banyak model pembelajaran atau strategi yang di terapkan dalam mencapai tujuan pendidikan. Misalnya dengan metode ceramah dan strategi pembelajaran peningkatan kemampuan berpikir. Pola pembelajaran yang di gunakan dalam SPPKB adalah guru memanfaatkan pengalaman siswa sebagai titik tolak berpikir. Sedangkan metode mengajar ceramah adalah metode mengajar dengan penyampaian informasi kepada sejumlah siswa atau dapat pula di katakan suatu cara mengajar dengan menyampaikan keterangan atau informasi tentang persoalan serta masalah lisan.

Berdasarkan hasil analisis penelitian menunjukkan bahwa dengan menerapkan model pembelajaran kelompok dengan metode ceramah melalui strategi pembelajaran peningkatan kemampuan berpikir (SPPKB) dapat meningkatkan hasil belajar siswa yang didukung dengan aktifitas belajar siswa. Perolehan nilai hasil evaluasi dan aktivitas belajar siswa dapat dilihat pada tabel dibawah ini :

Tabel 07. Rakafitulasi hasil observasi aktifitas diskusi kelompok siklus I dan II

\begin{tabular}{|l|l|l|l|l|}
\hline \multicolumn{1}{|c|}{ Keterangan } & Skor & \multicolumn{1}{|c|}{$\begin{array}{c}\text { Jumlah } \\
\text { Nilai }\end{array}$} & $\begin{array}{c}\text { Nilai Rata - } \\
\text { Rata }\end{array}$ & Kriteria \\
\hline $\begin{array}{l}\text { Aktifitas kelompok siklus } \\
\text { I }\end{array}$ & 453 & 74.4 & 2.6 & $\begin{array}{l}\text { Kurang } \\
\text { Aktif }\end{array}$ \\
\hline $\begin{array}{l}\text { Aktifitas kelompok siklus } \\
\text { II }\end{array}$ & 512 & 87.2 & 3.1 & Aktif \\
\hline
\end{tabular}

Berdasarkan hasil analisis bahwa pemberian tindakan pada siklus I belum dikatakan berhasil. Hal ini dilihat dari aktivitas siswa dengan nilai rata-rata 59,3 sedangkan persentase ketuntasan belajar sebesar 50\%, sedangkan target KKM secara kalsikal siswa minimal 80\%. Berdasarkan hal tersebut maka hasil belajar siswa pada siklus I belum memenuhi target yang ditetapkan.

Berdasarkan refleksi terhadap pelaksanaan tindakan yang dilakukan dan perbaikan pada siklus I, maka pada siklus II diberikan tindakan dan perbaikan dari kekurangan pada siklus II. Adapun tindakan yang dimaksud, siswa diberikan materi yang sama dengan model pembelajaran yang sama juga yakni dengan model pembelajaran diskusi kelompok dengan metode ceramah melalui strategi 
pembelajaran peningkatan kemampuan berpikir oleh guru dan yang paling utama adalah guru lebih mempersiapkan diri dalam menyampaikan meteri pelajaran sehingga mutu dan kualitas pertanyaan siswa lebih baik.

Pada siklus II ketuntasan belajar yang tercapai adalah 89,1 \% mengalami peningkatan dari siklus I yakni $50 \%$, hal ini menunjukkan bahwa hasil belajar ssiwa pada siklus II telah memenuhi target dalam KKM. Sedangkan rata-rata dan aktifitas data siswa diperoleh data dengan rata-rata 72,1 mengalami peningkatan dari siklus I sebesar 59,3. siklus II dilaksanakan seperti halnya pada siklus I, sedangkan pemberian tindakan dilakukan dengan penyempurnaan kekurangan-kekurangan pada siklus I.

Maka dapat dilihat bahwa model pembelajaran kelompok dengan metode ceramah melalui strategi pembelajaran peningkatan kemampuan berpikir (SPPKB) dapay meningkatkan hasil belajar siswa. Ini dapat dilihat dari kemampuan siswa yang lebih aktif, sehingga pemahaman mengenai konsep dapat ditempuh dengan baik. Dari hasil yang diperoleh ternyata menggunakan model diskusi kelompok dapat meningkatkan hasil belajar siswa.

Untuk mengetahui keberhasilan proses belajar mengajar adalah daya serap Terhadap pengajaran yang di ajarkan mencapai prestasi tinggi, baik secara individual maupun kelompok, serta tujuan pengajaran telah di capai oleh siswa baik secara individu maupun kelompok. ${ }^{7}$

Tabel 08. Rekafitulasi Hasil evaluasi dari siklus I, dan II, mengalami peningkatan yakni :

\begin{tabular}{|c|c|c|c|}
\hline No & Jenis kegiatan & Siklus I & Siklus II \\
\hline 1 & Rata - rata skor test & 59.3 & 72.1 \\
\hline 2 & Jumlah siswa tuntas & 14 & 25 \\
\hline 3 & $\begin{array}{c}\text { Persentase yang } \\
\text { tuntas }\end{array}$ & $50 \%$ & $89.1 \%$ \\
\hline
\end{tabular}

Tidak tercapainya ketuntasan belajar siswa pada siklus I disebabkan oleh beberapa hal diantara kurang aktifnya siswa dalam berdiskusi, pemberian motivasi dan apersepsi masih perlu di tingkatkan, pemberian contoh-contoh yang di kaitkan

${ }^{7}$ Djamarah \& Zein. Prestasi Belajar dan Kompetensi Guru. (Surabaya : Usaha Nasional 1997). 95 
dengan konteks kehidupan yang nyata masih kurang dan juga dalam hal pengelolaan kelas, dimana guru harus berkali-kali menenangkan siswa sebelum mulai pembelajaran, Hambatan yang di alami oleh guru pada siklus I diantaranya guru merasa kesulitan dalam menyajikan contoh (maalah) lain yang sesuai dengan kemampuan berpikir siswa. Hasil yang di peroleh pada siklus II juga belum tuntas, hal ini disebabkan pembagian tugas dalam satu kelompok belum terbagi dengan jelas, masih ada sebagian siswa yang masih mengandalkan pekerjaan temannya tanpa mau berusaha menberikan jawaban terhadap soal-soal yang diberikan. Ada juga siswa yang hanya diam memeperhatikan teman-temannya yang sedang bekerja. Hasil yang diperoleh pada siklus II telah mencapai ketuntasan belajar klasikal yaitu $80 \%$ siswa memperoleh nilai diatas.

\section{KESIMPULAN}

Berdasarkan pembahasan dari analisis yang peneliti lakukan yang berdasarkan pada data, maka dapat disimpulkan bahwa dengan penerapan metode ceramah yang dilakukan oleh guru melalui strategi pembelajaran peningkatan keterampilan berpikir dapat meningkatkan hasil belajar kelompok siswa kelas VII SMPN 2 Jerowaru dalam memahami konsep pada mata pelajaran ekonomi. Hal ini dilakukan tindakan kelas dengan dua siklus, dimana siklus I hasil belajar siswa dengan niali rata-rata sebesar 59.3 dan aktifitas kelompok dengan nilai rata-rata 2.6 dengan kriteria kurang aktif. Dan dilanjutkan kesiklus II dimana pada siklus II hasil belajar siswa dengan nilai ratarata sebesar 72.1 dan aktifitas kelompok dengan nilai rata-rata sebesar 87.2 dengan kriteria Aktif.

\section{DAFTAR PUSTAKA}

Aqib, dkk. (2008). Penelitian Tindakan Kelas, Untuk Guru SMP, SMA, SMK. Bandung: Yrama Widya.

Arikunto. (2002). Prosedur Penelitian Suatu Pendekatan Praktek. Jakarta: Rineka Cipta.

Djamarah, Zein. (1997). Prestasi Belajar dan Kompetensi Guru. Surabaya : Usaha Nasional.

Syaiful Bahri. (1994). Prestasi dan Konpentensi Guru. Surabaya: Usaha Nasional.

Syaiful Sagala. (2002). Kemampuan Propesi Guru. Jakarta: Rineka cipta.

Wayan Nurkancanta. (1986). Evaluasi pendidikan. Surabaya : Karya Usaha.

Wina Sanjaya. (2006). Strategi Pembelajaran. Bandung : Kencana 